\title{
Impact of awareness about history on trust and confidence in giving the donation - A case study of All India Pingalwara Charitable Society, Amritsar
}

\author{
Baljit Singh ${ }^{1}$, Dr. Fulbag Singh ${ }^{2}$ \\ ${ }^{I}$ (Research Scholar in the Department of Commerce and Business Management, Guru Nanak Dev University, \\ Amritsar, India) \\ ${ }_{2}^{2}$ (Professor in the Department of Commerce and Business Management, Guru Nanak Dev University, Amritsar, \\ India)
}

\begin{abstract}
Awareness about mission of Non-profit Organisation concerned, attitude of its personnel towards accomplishment of its mission and its contribution to the society play an important role in building the trust and confidence among donors in giving their donation to such organisation. This study investigates the impact of awareness about the unique history of All India Pingalwara Charitable Society (AIPCS) on the trust and confidence of its donors in giving the donation. It has been found that the donors, who are aware of AIPCS history, have more trust and confidence in giving the donation than the unaware donors. This study also examines relationship among awareness, trust and various demographic variables by applying the hierarchical log linear analysis. Finally, this study throws light on the categories of demographic variables on which more impact of awareness has been observed.
\end{abstract}

Keywords: Awareness, extent of awareness, trust \& confidence and donation.

\section{Introduction}

Every organisation has its own cause of establishment, especially non-profit organizations (NPOs) which are most active in social services (Hansman, 1987; Heitzmann, 2000). The mission statement of NPOs tells the cause of its establishment. The core of every non-profit organisation is its mission (Angelica, 2001; Glasrud, 2001). The history of NPO throws light on an attitude of its personnel towards the accomplishment of its mission and contribution to the society. If public are aware of NPO's contribution to the society, same may enthusiastic to donate money and render services for such NPOs. The philanthropic organisations strongly depend on the public's trust. The theories from very different disciplines such as economics, legal theory and political science imply that trust is of crucial importance for charitable giving. In the economic and legal theory, the existence of nonprofits next to public agencies and for-profit corporations is assumed to be based on the greater trustworthiness of NPOs due to the distribution constraint. The NPOs are not allowed to distribute profit to private parties (Hansmann, 1980, 1987, 1996). Therefore NPOs tends to justify their existence in emotional and moralistic terms.

The public's trust is dependent on various factors like mission of an organisation, attitude of organisation's personnel toward accomplishment of mission, contribution of organisation to the society and transparency in spending etc. In this research paper, the impact of history awareness on the trust and confidence of donors in giving the donation has been studied by taking the case study of All India Pingalwara Charitable Society (AIPCS), Amritsar. The impact of extent of history awareness has also been studied in this paper.

\section{The Brief Introduction of All India Pingalwara Charitable Society Amritsar (AIPCS)}

All India Pingalwara Charitable Society (AIPCS) is one of the largest multitasking non-profit organizations in India. It was founded by the Bhagat Puran Singh in the August, 1947 with a few discarded patients. At present, the AIPCS is taking care of approximately 1600 inmates by the end of March 2012. These inmates include a high percentage of the mentally retarded patients aging from the two years to eighty years. Besides these patients, a number of patients suffering from the TB, AIDS, blindness and deafness are included in them. The AIPCS is providing a free education and residence to the destitute, orphan and poor children. It also runs a number of schools for the normal, mentally retarded and deaf-and-dumb children in which no fee is being charged by it. Besides this, it is spreading awareness about the environment protection, zero budget natural farming and social evils by conducting a free seminars and distributing free literature in the various villages of India. It has its own printing press, which provides a wide range of literature free of cost for the guidance and reconstruction of man and society. It has been awarded with a heap of honours by the Indian Government for the above said contribution to the society. At present, the AIPCS has a number of branches 
Impact of awareness about history on trust and confidence in giving the donation - A case study of All working nationally and internationally for well-being of the society at large. It has a largest donors' base in the State of Punjab. The AIPCS accepts donation through cash by hand, cheque by hand or post, sponsoring someone, collection boxes fixed outside the holy Sikh shrines and public places, door to door collection, direct debit and in kind. The AIPCS communicates its performance to the public through leading newspapers and its own published literature from time to time.

\section{The Brief History of AIPCS}

AIPCS founded by Bhagat Puran Singh, has a unique history of its establishment. From the human perspective, the foundation stone of AIPCS was laid down by Bhagat Puran Singh in 1934, when on the birthday of Guru Nanak Dev Ji a crippled child was left outside Gurudwara Dehra Sahib Lahore (Now in Pakistan) by his parents. The Bhagat Puran Singh carried this child on his shoulders for 14 years with a roof of tin on his head and rearing him under the trees and saving him from thorns and stones. The journey was arduous and painful. But single handed, toiling day and night, in scorching heat and biting cold, in rains and thunderstorms, undeterred by adversaries, undaunted by criticism, he continued to pick up these wretched, helpless and dying but valuable creatures of God from wherever they could be found.

\section{The Brief Biography of Bhagat Puran Singh}

Bhagat Puran Singh ji born at village Rajewal, District, Ludhiana in June 04, 1904 set out in life for the service of the suffering humanity-the Greatest Religion. 'The curvilinear movement of life took him from his place of birth in a well-to-do Hindu family of Ludhiana, through hard times and with little formal education, to Gurdwara Dehra Sahib in Lahore. His mother had prepared him for the daunting tasks ahead. A crippled and mentally retarded child, spotted by him near the Gurdwara, confirmed him in his mission. As Jesus founded his church on Peter, his rock, Bhagat Puran Singh laid the foundation of his AIPCS on the ennobling presence of this beloved child named Piara Singh. Lahore's Dyal Singh Library helped him in self-education. The inhuman condition thrown up by the country's partition led him to the ideas of organised and institutionalised patientcare' (Naraynan, 2004). He founded AIPCS in August, 1947 with a few discarded patients. Now AIPCS is a very big home of human service. The Bhagatji's contributions in spreading awareness about the global dangers of environmental pollution and increasing soil erosion etc. are commendable. His dedication was awarded with series of honours by many quarters. Prestigious among these was the Padamshri Award in 1979 which he surrendered in the wake of the army attack on the Shri Harimandir Sahib in 1984. He left for his heavenly abode on August 5, 1992 after giving the charge of AIPCS to Dr. Inderjit Kaur. She has also devoted her life for the well being of helpless people on the lines of Bhagat Puran Singh. Her dedication has also been awarded by series of honours nationally as well as internationally.

\section{Review of Literature}

The review of relevant studies related to the research topic has been carried out and is given as follows: Bekkers (2003) examined the relationship between trust and charitable giving in his study. The researcher has found that charitable organizations can increase the public's trust by signaling their trustworthiness. The author has given the example of the Netherlands which shows how a system of accreditation can be an instrument for signaling trustworthiness to the public. The donors who are aware of the accreditation system have more trust in charities than those who are not aware of and they give more money to charitable causes. The author said charitable organizations have only limited control over the public's trust because it is also rooted in a general social trust in institutions and fellow citizens. The Author has also found that general social trust increases the amount which people give to charitable causes, even more so when people know about the accreditation system. Sargeant and Lee (2004) explored the relationship among trust, relationship commitment and donating behaviour. The technique of structural equation modelling is used to determine whether trust directly affects giving behaviour or whether its effects are mediated by commitment. The authors found that commitment plays a mediating role. The relationship commitment is maximized by the extent to which trust is present. Finally the authors conclude that communicating antecedents of trust to the donors and delivering a high standard of service from the fundraising department would be likely to increase levels of trust that would, in turn, build commitment and stimulate higher levels of charity giving.

Reinhardt (2009) explored the donor-recipient relationship in nonprofit funding and the effects of signaling on nonprofit resources. Multivariate analysis of data collected shows that donors channel their money to organizations exhibiting higher levels of reliability, accessibility, credibility, reputation and fundraising specialization. The author has found that nonprofits emit these signals through obtaining certification, employing staff members that speak various languages, acquiring the endorsement of international donors, and undergoing third-party audits and donors are giving their money to the most skillful signalers. Larger geographic ranges of service, more fulltime staff and religious affiliation also increase an organization's yearly intake. The author uses a signaling game in his study to sharpen understanding of nonprofit fundraising and 
derive the conditions under which signals will be credible. Interview and survey evidence gathered in Brazil indicate that signals of accessibility, reliability, and credibility attract the highest payoffs.

Sloan (2009) discussed the current landscape of accountability systems and accountability ratings and describes a model for estimating the effect of ratings systems on donor behaviour within the theoretical context of information asymmetry. Hypotheses are tested with nonprofit ratings for New York charities from the Better Business Bureau's Wise Giving Alliance to estimate the effect of accountability ratings on the amount of contributions an organization receives. Results indicate that the Wise Giving Alliance "pass" ratings have a statistically significant effect on the contributions received; however, "did not pass" ratings are insignificant.

Handy et al., (2010) explored consumers' abilities to identify nonprofits and their levels of trust in nonprofits as compared to for-profits and government organizations as well as their proclivity to patronize nonprofits as direct and indirect consumers. From a sample of 1,169 university students they found out that the students are more likely to trust as well as volunteer and donate to nonprofits' than other types of organizations. In purchasing health care and education, they are also more likely to patronize nonprofits. However, most cannot spontaneously identify the status of well known nonprofits, and in this regard they did not differ from the front line staff working for those organizations.

\section{Research Gap}

The issue of the donors' trust has received a broad attention of the researchers. Brody, 2002; Gronbjerg, 1993; Salamon, 1999, 2002, 2003; and Weisbrod, 1977 recognized the need for and promoted the use of accountability systems. Some authors namely; Benett \& DiLorenzo, 1994; Bies, 2001; Edwards \& Hulme, 1996; Kanter \& Summers, 1987 and Murray, 2001 focused specifically on the effectiveness of non-profit accountability systems. Sloan, 2009 discussed the systems of accountability and examined the effect of accountability ratings on donor behaviour. Bekkers, 2003 studied the relationship between the donors' trust and charitable giving. He also observed the effect of awareness about the accreditation system on the donors' trust. Sargeant and Lee, 2004 explored the relationship among the trust, relationship commitment and the donating behaviour. Reinhardt 2009 explored the donor-recipient relationship in the non-profit funding and the effects of signaling on its resources. Handy et al., 2010 explored the consumers' abilities to identify the non-profits and their levels of trust in the non-profits as compared to the for-profits and the government organizations as well as their proclivity to patronize the non-profits as direct and indirect consumers. However, no study has been found on the topic of impact of history awareness on the trust and confidence of donors in giving the donation from the available reviewed literature. The present study has been conducted for the same topic with the following objectives.

\section{Objectives}

The following pinpoint objectives have been set out for the present study.

1. To examine the impact of donors' awareness about AIPCS history on their trust and confidence in giving the donation.

2. To study the impact of extent of donors' awareness about AIPCS history on their trust and confidence.

3. To find out the categories of demographic variables who have more impact of awareness.

\section{Hypothesis}

The following two hypotheses have been constructed.

Hypothesis 1: The donors' awareness about NPO's history significantly affects the trust and confidence in giving the donation to the same NPO.

Hypothesis 2: The extent of awareness about NPO's history significantly affects the trust and confidence in giving the donation to the same NPO

\section{Data Collection}

To obtain the data for this study, a survey instrument was prepared, pretested and administered to a sample of 1000 donors of AIPCS. The donors were selected by the systematic random sampling from the list of donors provided by AIPCS. The present study is limited to the donors of the State of Punjab because AIPCS has the maximum number of branches in the State of Punjab. The questionnaire was sent to 1000 donors along with the prepaid return envelope. It was a paper-pencil survey. 348 questionnaires were filled up by the respondents. 44 questionnaires were found to be incomplete and excluded from the analysis. The remaining 304 questionnaires were used for the analysis. Moreover, to test the knowledge of history awareness about the AIPCS, telephone calls were made to all the 304 respondents selected for the analysis. The data were collected during the year 2009 and 2010. The Table 1 shows the demographic profile of 304 respondents. 
Table 1 Demographic profile

\begin{tabular}{|c|l|c|c|}
\hline Variable & \multicolumn{1}{|c|}{ Category } & Frequency & Percentage \\
\hline \multirow{3}{*}{ Gender } & Male & 199 & 65.5 \\
& Female & 105 & 34.5 \\
& Total & $\mathbf{3 0 4}$ & $\mathbf{1 0 0 . 0}$ \\
\hline \multirow{3}{*}{ Income } & Less than Rs. 15,000 & 165 & 54.3 \\
& Rs. 15,000 or more & 139 & 45.7 \\
& Total & $\mathbf{3 0 4}$ & $\mathbf{1 0 0 . 0}$ \\
\hline \multirow{5}{*}{ Education } & Undergraduate & 90 & 29.6 \\
& Graduate & 88 & 28.9 \\
& Postgraduate & 126 & 41.4 \\
& Total & $\mathbf{3 0 4}$ & $\mathbf{1 0 0 . 0}$ \\
\hline \multirow{5}{*}{ Age } & Less than 30 years & 103 & 33.9 \\
& 31 - 50 years & 104 & 34.2 \\
& 51 years and above & 97 & 31.9 \\
& Total & $\mathbf{3 0 4}$ & $\mathbf{1 0 0 . 0}$ \\
\hline \multirow{5}{*}{ Occupation } & Businessperson and Professional & 53 & 17.4 \\
& Government and Private Employees & 147 & 48.4 \\
& Students and others & 104 & 34.2 \\
& Total & $\mathbf{3 0 4}$ & $\mathbf{1 0 0 . 0}$ \\
\hline \multicolumn{2}{|c|}{ Source: Survey of AIPCS donors 2010, $N=304$} & & \\
& & &
\end{tabular}

\section{Research Methodology}

The Chi Square test has been applied for studying the impact of history awareness on the trust and confidence in giving the donation. For examining the relationship among history awareness/extent of history awareness, trust and demographic variables, Hierarchical Log Linear analysis has been used. The Odds ratios have been used to find out the effect size. The IBM SPSS statistics 20 (Evaluation version) software was used for applying the techniques. The tables have been used to demonstrate the results.

\section{Impact of History Awareness on the Trust And Confidence of Donors: An Evaluation}

To know the impact of history awareness on the trust and confidence of donors, the two multiple choice questions were asked from them. The first one was on history awareness about AIPCS and the second on trust and confidence in giving the donation to same. The cross tabulation as presented in Table 2 reveals the impact of awareness about the AIPCS history on the trust and confidence of donors in giving the donation to AIPCS. Out of the total 304 respondents, the 282 respondents ( $92.80 \%$ of total respondents) have been found to be aware of the AIPCS history and remaining 22 respondents (7.2\% of total respondents) are having no awareness about the history. Out of 282 respondents, the 227 respondents $(80.50 \%$ of total respondents who are aware of the history) have high trust and confidence in giving the donation to AIPCS.

Table 2: Association between awareness and trust

\begin{tabular}{|c|c|c|c|c|c|c|}
\hline \multirow{2}{*}{\multicolumn{3}{|c|}{ CROSS TABULATION }} & \multicolumn{2}{|c|}{$\begin{array}{l}\text { Trust and confidence in giving } \\
\text { the donation to AIPCS }\end{array}$} & \multirow{3}{*}{$\begin{array}{c}\text { Total } \\
\\
\mathbf{2 8 2} \\
100.0 \\
92.8 \\
92.8\end{array}$} & \multirow{3}{*}{$\begin{array}{c}\begin{array}{c}\text { Odds } \\
\text { Ratio }\end{array} \\
4.13\end{array}$} \\
\hline & & & High Degree & Low Degree & & \\
\hline \multirow{2}{*}{ 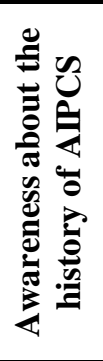 } & Aware & $\begin{array}{l}\text { Count } \\
\% \text { within Rows } \\
\% \text { within Columns } \\
\% \text { of Total }\end{array}$ & $\begin{array}{l}\mathbf{2 2 7} \\
80.5 \\
95.0 \\
74.7\end{array}$ & $\begin{array}{c}\mathbf{5 5} \\
19.5 \\
84.6 \\
18.1\end{array}$ & & \\
\hline & Not Aware & $\begin{array}{l}\text { Count } \\
\% \text { within Rows } \\
\% \text { within Columns } \\
\% \text { of Total }\end{array}$ & $\begin{array}{c}\mathbf{1 2} \\
54.5 \\
5.0 \\
3.9\end{array}$ & $\begin{array}{c}\mathbf{1 0} \\
45.5 \\
15.4 \\
3.3\end{array}$ & $\begin{array}{c}\mathbf{2 2} \\
100.0 \\
7.2 \\
7.2\end{array}$ & 1.20 \\
\hline & Total & $\begin{array}{l}\text { Count } \\
\% \text { within Rows }\end{array}$ & $\begin{array}{l}\mathbf{2 3 9} \\
78.6\end{array}$ & $\begin{array}{c}\mathbf{6 5} \\
21.4\end{array}$ & $\begin{array}{c}304 \\
100.0\end{array}$ & 3.44 \\
\hline
\end{tabular}


Impact of awareness about history on trust and confidence in giving the donation - A case study of All

\begin{tabular}{|l|c|c|c|c|}
\hline & $\begin{array}{l}\text { \% within Columns } \\
\text { \% of Total }\end{array}$ & $\begin{array}{c}100.0 \\
78.6\end{array}$ & $\begin{array}{c}100.0 \\
21.4\end{array}$ & 100.0 \\
\hline Chi-square test values & $8.176^{\mathrm{a}}(0.004)^{*}$ & $6.705^{\mathrm{b}}(0.010)^{*}$ & $6.915^{\mathrm{c}}(0.009)^{*}$ & $(0.012)$ \\
\hline Symmetric measures & $0.162^{\mathrm{e}}(0.004)^{*}$ & $0.164^{\mathrm{f}}(0.004)^{*}$ & \\
\hline
\end{tabular}

With respect to the donors not having awareness, only 12 donors (54.50\% of total unaware donors) have high trust and confidence. After meeting all the assumptions of Chi-Square test, it has been found that there exists significant association between awareness about the AIPCS history and trust \& confidence in giving the donation to AIPCS. The Pearson chi-square value of 8.176 has been found to be statistically highly significant at 1 percent level. All the other chi-square tests namely continuity correction, likelihood ratio and Fisher's exact test have confirmed the results of main chi-square test, indicating that awareness about history of AIPCS has a significant effect on trust and confidence in giving donation to AIPCS. The odds ratio indicates that the donors having awareness are 3.44 times more likely to have high trust and confidence in giving the donation than the donors not having awareness. The symmetric measures namely contingency coefficient and phi-value show low degree of correlation between the two variables.

In order to examine the impact of demographic variables on the above said variables namely awareness about the AIPCS history and trust and confidence of donors in giving the donation to AIPCS, the technique of Log linear analysis has been applied. The Table 3 depicts the results of Hierarchical Log Linear analysis of awareness, trust and demographic variables. It starts with the test of K-way and higher order effects. The column two represents the same. It has been found that the demographic variable gender, income and age have shown the significant 2-way and higher order effects. It implies that removing of 3-way and higher order interaction will not have significant detrimental effect on the model. This is due to insignificant interaction of the demographic variables (gender and age) with the trust variable and demographic variable income with the awareness variable. On the other hand, education and occupation have shown the significant 1-way and higher order effects. It implies that removing of 2-way and higher order interaction will not show significant detrimental effect on the model. This is due to insignificant interaction of the demographic variables (education and occupation) with the trust and awareness variables. The variable awareness has found to be the most significant effect in all the five models. It indicates that history awareness plays a significant role in building the trust and confidence among donors.

Table 3: Hierarchical log linear analysis of awareness, trust and demographic variables

\begin{tabular}{|c|c|c|c|c|c|c|}
\hline \multirow{2}{*}{$\begin{array}{l}\text { Demographic } \\
\text { rariable }\end{array}$} & \multirow{2}{*}{$\begin{array}{l}\text { K-way \& higher } \\
\text { order effects }\end{array}$} & \multirow{2}{*}{$\begin{array}{c}\text { Most important effect } \\
\text { in the model }\end{array}$} & \multirow{2}{*}{ Final model } & \multicolumn{2}{|l|}{ Odds } & \multirow{2}{*}{$\begin{array}{l}\text { Likelihood } \\
\text { ratio }\end{array}$} \\
\hline & & & & Equation & Ratio & \\
\hline \multirow{2}{*}{ Gender } & \multirow{2}{*}{$\begin{array}{l}\text { 2-way and higher } \\
\text { order effects }\end{array}$} & \multirow{2}{*}{ Awareness } & $\begin{array}{l}\text { Gender } x \\
\text { anareness** }\end{array}$ & 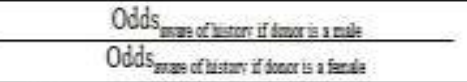 & 7.50 & \multirow{2}{*}{3.74} \\
\hline & & & $\begin{array}{l}\text { Awareness } x \\
\text { trust }^{*}\end{array}$ & 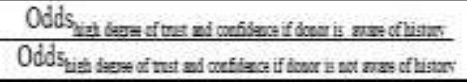 & 3.44 & \\
\hline \multirow{2}{*}{ Income } & \multirow{2}{*}{$\begin{array}{l}\text { 2-way and higher } \\
\text { order effects* }\end{array}$} & \multirow{2}{*}{ Awareness } & Income $x$ trust $^{*}$ & 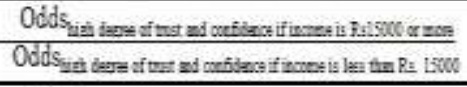 & 2.44 & \multirow{2}{*}{1983} \\
\hline & & & $\begin{array}{l}\text { Awarenes3 } x \\
\text { trust" }\end{array}$ & 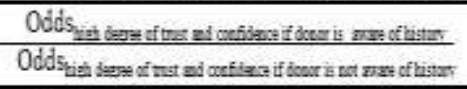 & 3.44 & \\
\hline \multirow[t]{2}{*}{ Education } & \multirow{2}{*}{$\begin{array}{l}\text { 1-way and higher } \\
\text { order effects }^{*}\end{array}$} & \multirow[t]{2}{*}{ Awareness } & $\begin{array}{l}\text { Awarenes3 } x \\
\text { trust }^{*}\end{array}$ & 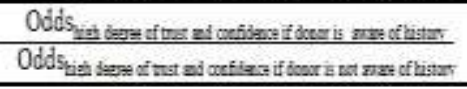 & 3.44 & \multirow[t]{2}{*}{2.901} \\
\hline & & & Education ${ }^{*}$ & - & - & \\
\hline \multirow{2}{*}{ Age } & \multirow{2}{*}{$\begin{array}{l}\text { 2-way and higher } \\
\text { order effects* }\end{array}$} & \multirow{2}{*}{ Awareness } & $\begin{array}{l}\text { Agex } \\
\text { awareness* }\end{array}$ & 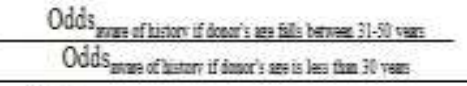 & 2.36 & \multirow{2}{*}{4245} \\
\hline & & & $\begin{array}{l}\text { Awareness } x \\
\text { trust }\end{array}$ & 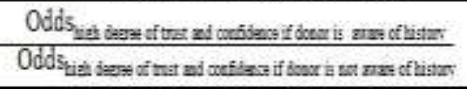 & 3.44 & \\
\hline \multirow[b]{2}{*}{ Occupation } & \multirow{2}{*}{$\begin{array}{l}\text { 1-iray and higher } \\
\text { order effects }\end{array}$} & \multirow[b]{2}{*}{ Awareness } & Occupation ${ }^{*}$ & - & - & \multirow[b]{2}{*}{3.523} \\
\hline & & & $\begin{array}{l}\text { Awarenes5 } x \\
\text { trust* }\end{array}$ & 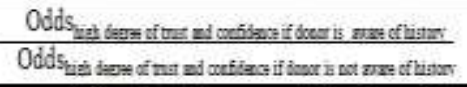 & 3.44 & \\
\hline
\end{tabular}


Impact of awareness about history on trust and confidence in giving the donation - A case study of All The Odds ratio of Awareness $\times$ trust interaction has confirmed this finding. With the help of Odds ratios, the following four conclusions may be drawn from the Table 3:

1. The donors having awareness are 3.44 times more likely to have high trust and confidence in giving the donation than the donors not having awareness.

2. The male donors are 7.50 times more likely to be aware than the female donors.

3. The donors having income level of Rs. 15000 or more are 2.44 times more likely to have high trust and confidence in giving the donation to AIPCS than the donors whose income is less than Rs. 15000.

4. The donors, whose age is between 31-50 years, are 2.36 times more likely to be aware of history than the donors having the age of less than 30 years.

In order to find out which categories of demographic variables have been more influenced by history awareness, the interaction of awareness and trust variables has been calculated independently with respect to each category of demographic variable. The Table 4 shows the Awareness and Trust interaction of all categories of demographic variables.

Table 4: Interaction of awareness and trust variables (demographic variable wise)

\begin{tabular}{|c|c|c|c|c|}
\hline $\begin{array}{c}\text { Demographic } \\
\text { variable }\end{array}$ & Category & $\begin{array}{c}\text { Significance } \\
\text { of interaction }\end{array}$ & $\begin{array}{l}\text { Odds } \\
\text { ratio }^{2}\end{array}$ & $\begin{array}{c}\text { Categories having } \\
\text { more impact of } \\
\text { awareness on trust \& } \\
\text { confidence }\end{array}$ \\
\hline \multirow{2}{*}{ Gender } & Male & Yes* & 15.4 & $\sqrt{ }$ \\
\hline & Female & Yes*** & 2.65 & \\
\hline \multirow{2}{*}{ Income } & Less than Rs. 15000 & Yes** & 2.92 & \\
\hline & Rs. 15000 or more & No & 3.41 & $\sqrt{ }$ \\
\hline \multirow{3}{*}{ Education } & Undergraduate & No & 1.26 & \\
\hline & Graduate & Yes** & 4.71 & $\sqrt{ }$ \\
\hline & Postgraduate & Yes** & 4.04 & \\
\hline \multirow{3}{*}{ Age } & Up to 30 years & No & 2.27 & \\
\hline & $31-50$ years & Yes* & 8.62 & $\sqrt{ }$ \\
\hline & 51 years or above & $\mathrm{NA}^{3}$ & $\mathrm{NA}^{3}$ & \\
\hline \multirow{3}{*}{ Occupation } & Businessperson and Professional & $\mathrm{NA}^{3}$ & $\mathrm{NA}^{3}$ & \\
\hline & Government and Private Employees & Yes** & 4.71 & $\sqrt{ }$ \\
\hline & Students and others & No & 1.84 & \\
\hline \multicolumn{5}{|c|}{ ource: Survey of AIPCS donors 2010, $N=304$} \\
\hline \multicolumn{4}{|c|}{$\begin{array}{l}\text { 1. Awareness } \times \text { trust interaction } \\
\text { Odds } h \text { high trust and confidence if donor is aware of history }\end{array}$} & ** $\quad$ Significant at $5 \%$ \\
\hline
\end{tabular}

3. Chi-square test cannot be applied due to violation of assumptions.

It has been found that out of thirteen categories, seven categories have shown significant interaction between awareness and trust. Only four categories namely the donors, whose, income is Rs. 15000 or more, age is of not more than 30 years, education is less than graduation and who are students, have shown insignificant interaction. With respect to remaining two categories viz. donors having age of 51 years or above and donors having occupation of business and profession, chi-square test has not been applied due to violation of assumptions. Further the following inferences may be drawn from the Table 4.

1. The impact of awareness has been found more in male donors than the female donors. The male donors, who are aware of history, are 15.40 times more likely to have high degree of trust and confidence in giving the donation than who are unaware of history. However, the aware female donors are 2.65 times more likely to have high degree of trust and confidence in giving donation than the unaware.

2. With respect to demographic variable income, the donors having income level of Rs. 15000 or more have been found with the greater impact of awareness than the donors having income level of less than Rs. 15000 .

3. It has been found out that the donors having education not more than graduation have revealed the higher impact of awareness on their trust and confidence than the undergraduate and post graduate donors.

4. The impact of awareness has been observed more in case of donors having age group of $31-50$ years than the other age groups. 
Impact of awareness about history on trust and confidence in giving the donation - A case study of All

5. The donors, who are government or private employees, have shown the bigger impact of awareness on their trust and confidence than the other categories of occupation viz. business/profession and student.

\section{Impact of the Extent of History Awareness on the Trust and Confidence of Donors: An Analysis}

As it has been earlier stated in the data collection part, to minimize the socially desirable responding, an attempt has been made to test the knowledge of selected donors about the history of AIPCS. The less percentage of unaware donors (i.e. merely 7.2 percent) insisted to test the same. The two variables has been used to show the results viz. completely aware and somewhat aware. The 'complete history awareness' means the donor had a full knowledge of AIPCS history stated in the introductory section of the paper. The term 'somewhat awareness' means the donor only knew that, "Bhagat Puran Singh was the founder of AIPCS and he started AIPCS with a crippled child Piara Singh." The Table 5 depicts the impact of the extent of history awareness on the trust and confidence of donors. It has been found out that 158 respondents (56 percent of total aware respondents) were completely aware of history. However, the 124 respondents (44 percent of total aware respondents) were found to be somewhat aware about AIPCS history. Out of 158 completely aware respondents, 133 respondents ( 84.20 percent of completely aware) have high degree of trust and confidence in giving the donation to AIPCS. With respect to 124 somewhat aware respondents, 94 respondents $(75.80$ percent of somewhat aware) have high degree of trust and confidence. After meeting all the assumptions of Chi-Square test, it has been found that there exists significant association between extent of history awareness and trust \& confidence in giving the donation to AIPCS. The Pearson chi-square value of 3.101 has been found to be statistically significant at 10 percent level. All the other chi-square tests have confirmed the results of main chisquare test except the continuity correction. It indicates that extent of history awareness has a significant effect on trust and confidence in giving the donation to AIPCS. The odds ratio indicates that the donors, who have complete awareness about history, are 1.70 times more likely to have high trust and confidence in giving the donation than the donors who are somewhat aware. The symmetric measures namely contingency coefficient and phi-value show low degree of correlation between the two variables.

Table 5: Association between Extent of History Awareness and Trust

\begin{tabular}{|c|c|c|c|c|c|c|}
\hline & \multirow{2}{*}{\multicolumn{2}{|c|}{ CROSS TABULATION }} & \multicolumn{2}{|c|}{$\begin{array}{l}\text { Trust and Confidence in } \\
\text { Giving Donation to } \\
\text { Pingalwara }\end{array}$} & \multirow[t]{2}{*}{ Total } & \multirow[t]{2}{*}{$\begin{array}{l}\text { Effect } \\
\text { Size }\end{array}$} \\
\hline & & & High Degree & Low Degree & & \\
\hline \multirow{2}{*}{ 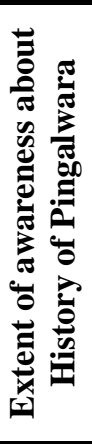 } & $\begin{array}{c}\text { Completely } \\
\text { Aware }\end{array}$ & $\begin{array}{l}\text { Count } \\
\% \text { within Rows } \\
\% \text { within } \\
\text { Columns } \\
\% \text { of Total }\end{array}$ & $\begin{array}{c}133 \\
84.20 \% \\
58.60 \% \\
47.20 \% \\
\end{array}$ & $\begin{array}{c}25 \\
15.80 \% \\
45.50 \% \\
8.90 \% \\
\end{array}$ & $\begin{array}{c}158 \\
100.00 \% \\
56.00 \% \\
56.00 \% \\
\end{array}$ & 5.32 \\
\hline & $\begin{array}{l}\text { Somewhat } \\
\text { Aware }\end{array}$ & $\begin{array}{l}\text { Count } \\
\% \text { within Rows } \\
\% \text { within } \\
\text { Columns } \\
\% \text { of Total }\end{array}$ & $\begin{array}{c}94 \\
75.80 \% \\
41.40 \% \\
33.30 \% \\
\end{array}$ & $\begin{array}{c}30 \\
24.20 \% \\
54.50 \% \\
10.60 \%\end{array}$ & $\begin{array}{c}124 \\
100.00 \% \\
44.00 \% \\
44.00 \%\end{array}$ & 3.13 \\
\hline \multicolumn{2}{|r|}{ Total } & $\begin{array}{l}\text { Count } \\
\% \text { within Rows } \\
\% \text { within } \\
\text { Columns } \\
\% \text { of Total }\end{array}$ & $\begin{array}{c}227 \\
80.50 \% \\
100.00 \% \\
80.50 \% \\
\end{array}$ & $\begin{array}{c}55 \\
19.50 \% \\
100.00 \% \\
19.50 \% \\
\end{array}$ & $\begin{array}{c}282 \\
100.00 \% \\
100.00 \% \\
100.00 \% \\
\end{array}$ & 1.70 \\
\hline \multicolumn{2}{|c|}{$\begin{array}{l}\text { Chi-Square Test } \\
\text { Values }\end{array}$} & $3.101^{\mathrm{a}}(0.078)^{* * *}$ & $2.591^{b}(0.108)$ & $\begin{array}{r}3.080 \\
(0.079) \\
\end{array}$ & \multicolumn{2}{|c|}{$(0.096)^{\mathrm{d} * * *}$} \\
\hline \multicolumn{2}{|c|}{ Symmetric Measures } & $0.104^{\mathrm{e}}(0.078)^{* * *}$ & \multicolumn{2}{|l|}{$\begin{array}{c}0.105^{\mathrm{f}} \\
(0.078)^{* * *} \\
\end{array}$} & & \\
\hline \multicolumn{5}{|c|}{$\begin{array}{l}\text { Source: Survey of AIPCS donors } 2010, N=304 \\
\text { a. } \\
\text { b. Pearson Chi-Square } \\
\text { c. } \quad \text { Continuity Correction (Computed only for a } 2 \times 2 \text { table) } \\
\text { d. Fisher's Exact Test (Computed only for a } 2 \times 2 \text { table) }\end{array}$} & $\begin{array}{l}\mathrm{S} \text { in parenthese } \\
\text { Contingency } \\
\text { Phi Value ( } \\
\text { Significant } \\
\text { Significant }\end{array}$ & $\begin{array}{l}\text { low } p \text { values } \\
\text { efficient } \\
\text { a } 2 \times 2 \text { table) } \\
\% \\
0 \%\end{array}$ \\
\hline
\end{tabular}


In order to find the interaction of demographic variables with the other two variables viz. extent of history awareness and trust \& confidence in giving the donation, the technique of Hierarchical Log Linear Analysis has been used. The Table 6 demonstrates the result of analysis. It is apparent from the same table that all the demographic variables have shown the significant 2-way and higher order effects except the gender. It implies that removing of 3-way and higher order effects will not show significant detrimental effect to the models. The variable trust and confidence in giving the donation has been found out the most important effect in all the five models. All the five models contain the significant extent of history awareness and trust interaction. It indicates that the extent of history awareness has shown the impact on the degree of trust and confidence of the donors. The following inferences have drawn from the Odds ratios.

1. The donors having complete history awareness are 1.70 times more likely to have high degree of trust and confidence in giving the donation to AIPCS than the somewhat aware donors.

2. The donors, who are earning Rs. 15000 or more, are 2.34 times more likely to have high degree of trust and confidence than the donors who are getting less than Rs. 15000.

3. The post graduate donors are 2.38 times more likely to have complete history awareness than the graduate donors and 1.79 times more than the under graduate donors. However, the graduate donors are 1.33 times more likely to have complete history awareness than the under graduate donors. It indicates that education plays a significant role in creating the level of awareness and level of awareness plays a vital role in building trust and confidence among donors.

4. The donors, who are studying, are 2.03 times more likely to have complete history awareness than the government and private employees and 1.71 times more than the businessperson and professionals. Moreover business person and professionals are 1.83 times more likely to have complete history awareness than the government and private employees.

Table 6: Hierarchical log linear analysis of extent of awareness, trust and demographic variable

\begin{tabular}{|c|c|c|c|c|c|c|}
\hline \multirow{2}{*}{$\begin{array}{c}\text { Demographic } \\
\text { variable }\end{array}$} & \multirow{2}{*}{$\begin{array}{l}\text { K-way \& higher } \\
\text { order effects }\end{array}$} & \multirow{2}{*}{$\begin{array}{l}\text { Most important } \\
\text { effect in the model }\end{array}$} & \multirow{2}{*}{ Final model } & \multicolumn{2}{|l|}{ Odds } & \multirow{2}{*}{$\begin{array}{l}\text { Likelihood } \\
\text { ratio }\end{array}$} \\
\hline & & & & Equation & Ratio & \\
\hline \multirow[t]{2}{*}{ Gender } & \multirow{2}{*}{$\begin{array}{l}\text { 1-way and higher } \\
\text { order effects }^{*}\end{array}$} & \multirow[t]{2}{*}{ Trust } & 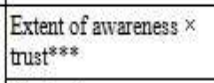 & 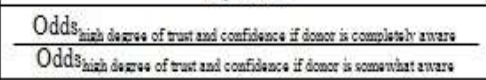 & 1.70 & \multirow[t]{2}{*}{4.029} \\
\hline & & & Gender $^{*}$ & 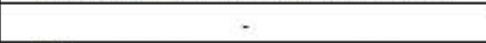 & - & \\
\hline \multirow{2}{*}{ Income } & \multirow{2}{*}{$\begin{array}{l}\text { 2-way and higher } \\
\text { order effects }{ }^{*}\end{array}$} & \multirow{2}{*}{ Trust } & Income $\times$ trust $^{*}$ & 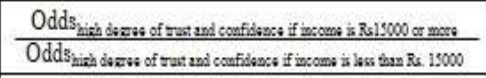 & 2.34 & \multirow{2}{*}{2.775} \\
\hline & & & $\begin{array}{l}\text { Extent of awareness } x \\
\text { trust }^{* * 8}\end{array}$ & 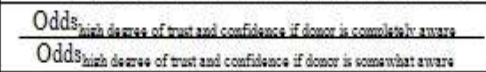 & 1.70 & \\
\hline \multirow{4}{*}{ Education } & \multirow{4}{*}{$\begin{array}{l}\text { 2-way and higher } \\
\text { order effects }\end{array}$} & \multirow{4}{*}{ Trust } & \multirow{3}{*}{$\begin{array}{l}\text { Education } \times \text { extent of } \\
\text { awareness }{ }^{8}\end{array}$} & 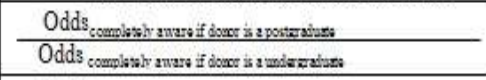 & 2.38 & \multirow{4}{*}{1.141} \\
\hline & & & & 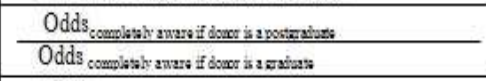 & 1.79 & \\
\hline & & & & 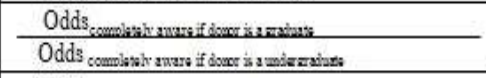 & 1.33 & \\
\hline & & & \begin{tabular}{|l|}
$\begin{array}{l}\text { Extent of awareness } x \\
\text { tust } * *\end{array}$ \\
\end{tabular} & 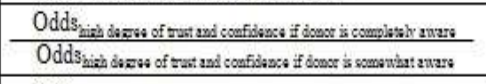 & 1.70 & \\
\hline Age & $\begin{array}{l}\text { 2-way and higher } \\
\text { order effects }^{* * *}\end{array}$ & Trust & \begin{tabular}{|l|} 
Extent of awareness $\times$ \\
trust \\
\end{tabular} & 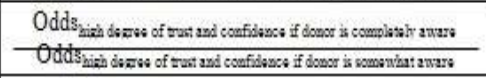 & 1.70 & 11.162 \\
\hline \multirow{5}{*}{ Occupation } & \multirow{5}{*}{$\begin{array}{l}\text { 2-wray and higher } \\
\text { order effects }\end{array}$} & \multirow{5}{*}{ Trust } & & 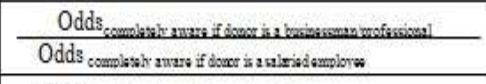 & 1.83 & \multirow{5}{*}{4.758} \\
\hline & & & $\begin{array}{l}\text { Occupation } \times \text { extent of } \\
\text { awareness }{ }^{* 8}\end{array}$ & 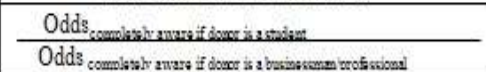 & 1.71 & \\
\hline & & & & 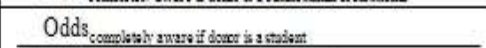 & 203 & \\
\hline & & & & 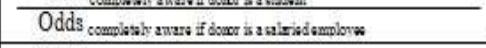 & 2.03 & \\
\hline & & & $\begin{array}{l}\text { Extent of awareness } X \\
\text { trust }^{* * *}\end{array}$ & 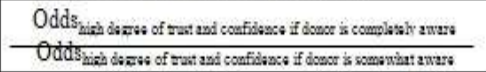 & 1.70 & \\
\hline
\end{tabular}

In order to find out which categories of demographic variables have been more influenced by the extent of history awareness, the interaction of extent of awareness and trust variables has been calculated independently with respect to each category of demographic variable. The Table 7 shows the Extent of Awareness $\times$ Trust interaction of all categories of demographic variables. It is apparent from the same table that out of thirteen categories, only four categories (viz. female, income of less than Rs. 15000, age of 51 years or above and students) have shown significant interaction between extent of awareness and trust. The remaining nine categories have shown insignificant interaction. 
Impact of awareness about history on trust and confidence in giving the donation - A case study of All

Table 7: Interaction of Extent of awareness and trust variable (demographic variable wise)

\begin{tabular}{|c|c|c|c|c|}
\hline $\begin{array}{c}\text { Demographic } \\
\text { variable }\end{array}$ & Category & $\begin{array}{l}\text { Significance of } \\
\text { interaction }^{1}\end{array}$ & $\begin{array}{l}\text { Odds } \\
\text { ratio }^{2}\end{array}$ & $\begin{array}{l}\text { Categories having more } \\
\text { impact of awareness on } \\
\text { trust \& confidence }\end{array}$ \\
\hline \multirow{2}{*}{ Gender } & Male & No & 1.33 & \\
\hline & Female & Yes** & 3.06 & $\sqrt{ }$ \\
\hline \multirow{2}{*}{ Income } & Less than Rs. 15000 & Yes*** & 1.97 & $\sqrt{ }$ \\
\hline & Rs. 15000 or more & No & 1.64 & \\
\hline \multirow{3}{*}{ Education } & Undergraduate & No & 1.88 & \\
\hline & Graduate & No & 1.13 & \\
\hline & Postgraduate & No & 2.13 & $\sqrt{ }$ \\
\hline \multirow{3}{*}{ Age } & Up to 30 years & No & 1.50 & \\
\hline & $31-50$ years & No & 0.86 & \\
\hline & 51 years or above & Yes* & 3.60 & $\sqrt{ }$ \\
\hline \multirow{3}{*}{ Occupation } & Businessperson and Professional & No & 0.92 & \\
\hline & $\begin{array}{l}\text { Government and Private } \\
\text { Employees }\end{array}$ & No & 1.48 & \\
\hline & Students and others & Yes** & 3.28 & $\sqrt{ }$ \\
\hline
\end{tabular}

Source: Survey of AIPCS donors 2010, $N=304$

1. Awareness $\times$ trust interaction

2. Odds Ratio $=\frac{\text { Odds high trust and confidence if donor is completely aware of history }}{\text { Odds high trust and confidence if donor is somewhat aware of history }}$

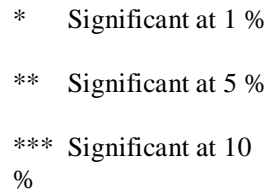

3. Chi-square test cannot be applied due to violation of assumptions.

The following inferences have been drawn from the Table 7.

1. The impact of extent of history awareness has been found more in the female donors than male donors.

2. The donors having income level of less than Rs. 15000 have been found with the greater impact of extent of history awareness than the donors having income level of Rs. 15000 or more.

3. It has been found out that the impact of the extent of history awareness on the trust and confidence among donors increases with the increase in the level of education.

4. The impact of extent of awareness has been observed more in case of donors having the age group of 51 years or more than the other age groups.

5. The donors, who are studying, have shown the greater impact of extent of history awareness.

\section{Conclusion}

This study reveals the impact of donors' awareness about NPO's history on the trust and confidence in giving the donation to the same. From the above discussion, it can be concluded that awareness about history of All India AIPCS Charitable Society plays an important role in building the trust and confidence among its donors. It has been found that the completely aware donors have high degree of trust and confidence than the somewhat aware donors. Both the hypotheses support the findings of study. This study reveals that the impact of awareness has been found more in male donors than the female donors. However, the impact of extent of awareness is found to be more in female donors than the male. With respect to demographic variable income, the impact of awareness has been found more in the donors having income of Rs. 15000 or more. On the contrary, the impact of extent of awareness is found to be more in the donors having income of less than Rs. 15000. This study further divulges that the level of awareness increases with increase in the level of education and awareness plays a significant role in building trust and confidence among donors. Moreover, the impact of awareness has been observed more in case of donors having the age group of $31-50$ years than the other age groups. However, the impact of extent of awareness has been seen more in the donors having the age group of 51 years or more. Lastly, this study discloses that the government and private employees have been more influenced by the history awareness. 


\section{Recommendations to AIPCS}

On the basis of the above findings and conclusions drawn from the analysis, the following recommendation can be made to the AIPCS.

1. AIPCS should create awareness about history, services provided and its contribution to the society through print and electronic media.

2. AIPCS should create history awareness among women of the society because a woman can aware her whole family. In this study, the impact of awareness is found to be much less in the women than men but the impact of extent of awareness is more in women.

3. AIPCS should make the efforts to create history awareness among less educated people by conducting public seminars.

4. AIPCS should also create awareness among young generation because the impact of extent of awareness has been found more in student category.

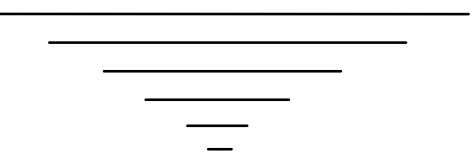

\section{References}

[1] Angelica, E. (2001) The Fieldstone Alliance Nonprofit Guide to Crafting Effective Mission and Vision Statements, Minneapolis, Amherst H. Wilder Foundation.

[2] Bekkers, R. (2003) 'Trust, Accreditation, and Philanthropy in the Netherlands', Nonprofit and Voluntary Sector Quarterly, 32, 596-615.

[3] Bennett, J. T., and DiLorenzo, T. J. (1994). Unhealthy charities: Hazardous to your health and wealth, Basic Books, New York.

[4] Bies, A. L. (2001). Accountability, organizational capacity, and continuous improvement: Findings from Minnesota's nonprofit sector. In P. Barber (Ed.), Accountability: A challenge for charities and fundraisers (Vol. 31, pp. 7-22), Jossey-Bass, San Francisco.

[5] Brody, E. (2002). Accountability and public trust. In L. S. Salamon (Ed.), The state of nonprofit America (pp. 471-498), Brookings Institution Press, Washington, DC.

[6] Edwards, M., and Hulme, D. (Eds.). (1996). Beyond the magic bullet: NGO performance and Accountability in the post-cold war world, Kumarian Press, West Hartford, CT.

[7] Glasrud, B. (2001) 'Your Mission Has a Mission' Nonprofit World, 19(5), 35-37.

[8] Gronbjerg, K. A. (1993). Understanding nonprofit funding: Managing revenues in social services and community development organizations, Jossey-Bass, San Francisco.

[9] Handy et al., (2010) 'The Discerning Consumer: Is Nonprofit Status a Factor?', Nonprofit and Voluntary Sector Quarterly, 39, 866-883.

[10] Hansmann, H. (1980) 'The Role of Nonprofit Enterprise', Yale Law Journal, 89(5), 835-901.

[11] Hansmann, H. (1987) 'Economic Theories of Nonprofit Organizations'. In Powell, W. W. (eds) The Nonprofit Sector: A Research Handbook, New Haven, Yale University Press.

[12] Hansmann, H. (1996) The Ownership of Enterprise, Cambridge, MA, Belknap.

[13] Heitzmann, K. (2000) 'The Role of Third Sector Organizations in Specific Policy Fields: Contrasting Nonprofit Theory and Empirical Findings-The Case of Austria', paper prepared for the Fourth International Conference of the ISTR, Dublin.

[14] Kanter, R. M., and Summers, D. V. (1987). Doing well while doing good: Dilemmas of performance measurement in nonprofit organizations and the need for a multiple-constituency approach. In W. Powell (ed.), The nonprofit sector: A research handbook (pp. 154-166), Yale University Press, New Haven, CT.

[15] Murray, V. (2001). The state of evaluation tools and systems for nonprofit organizations. In P. Barber (ed.), Accountability: A challenge for charities and fundraisers (pp. 39-50), Jossey-Bass, San Francisco.

[16] Naraynan, V. N. (2004) 'Remembering a Sage' accessed at http://www.pingalwaraonline.org/about_pingal/bhagatji-art-3a.html on August 12, 2010.

[17] Reinhardt, G. Y. (2009) 'Matching Donors and Nonprofits: The Importance of Signaling in Funding Awards', Journal of Theoretical Politics, 21(3), 283-309.

[18] Sargeant, A., \& Lee, S. (2004) 'Donor Trust and Relationship Commitment in the U.K. Charity Sector: The Impact on Behavior', Nonprofit and Voluntary Sector Quarterly, 33, 185-202.

[19] Salamon, L. S. (1999). America's nonprofit sector: A primer, Foundation Center, New York.

[20] Salamon, L. S. (Ed.). (2002). The state of the nonprofit sector, Brookings Institution Press, Washington, DC.

[21] Salamon, L. S. (2003). The resilient sector: The state of nonprofit America, Brookings Institution Press, Washington, DC.

[22] Sloan, M. F. (2009) 'The Effects of Nonprofit Accountability Ratings on Donor Behavior', Nonprofit and Voluntary Sector Quarterly, 38, 220-236.

[23] Weisbrod, B. (1977). The voluntary nonprofit sector: An economic analysis, Lexington Books, Lexington, MA. 